DOI: $10.17516 / 1997-1370-0686$

УДК $332.1 ; 304.442$

\title{
Evaluation of Human Capital in the Macroregion (on the Example of the Yenisey Siberia)
}

\author{
Irina P. Vorontsova, Anna R. Semenova, \\ Ludmila K. Vitkovskaya and Ivan A. Drobyshev* \\ Siberian Federal University \\ Krasnoyarsk, Russian Federation
}

Received 21.08.2020, received in revised form 29.08.2020, accepted 11.11.2020

\begin{abstract}
The article is devoted to the problem of measuring and estimating the human capital of the natural resource macroregion, whose territory is characterized by a high level of social and economic asymmetry. It presents results of testing of modified index of human capital in context of interdisciplinary approach. The study was based on survey findings, along with statistical data. The satisfaction of the population with the quality of life is a key indicator of the dynamics of human capital in the long term. The authors give recommendations on the development of information support of territorial policy.
\end{abstract}

Keywords: evaluation of human capital, Yenisey Siberia microregion, socio-economic indices, quality of life.

The study has been carried out with the financial support of the Russian Foundation for Basic Research, the Government of Krasnoyarsk Krai, the Krasnoyarsk Region Science and Technology Support Fund under the research project "Formal Approaches and Practice of Measuring Human Capital in the Context of Assessing the Quality of Life of a Territory population (on the example of the Yenisei Siberia macroregion)" No: 18-410-242006 (r_mk).

Research area: economy.

Citation: Vorontsova, I.P., Semenova, A.R., Vitkovskaya, L.K., Drobyshev, I.A. (2020). Evaluation of human capital in the macroregion (on the example of the Yenisey Siberia). J. Sib. Fed. Univ. Humanit. Soc. Sci., 13(11), 1808-1818. DOI: 10.17516/1997-1370-0686.

(c) Siberian Federal University. All rights reserved

* Corresponding author E-mail address: ivorontsova@sfu-kras.ru; asemenova@sfu-kras.ru; LVitkovskaya@sfu-kras.ru ORCID: 0000-0001-5777-737X (Vorontsova) 


\section{Introduction}

The article presents the results of an interdisciplinary research of socio-economic and socio-cultural factors that affect the quality and dynamics of human capital at the level of individual territories on the example of the Yenisey Siberia macroregion (Krasnoyarsk Krai, the Republics of Tyva and Khakassia).

Two types of non-linear index measurements have been used to compare significance of individual socio-economic and socio-cultural factors at the regional and sub-regional level:

Greenberg A Index (Greenberg, 1956), also called the Gini-Simpson Index (Gini, 1912; Simpson, 1949);

a one-parameter class of degree indexes (Davydov, Weber, 2016), which includes the Greenberg A Index as a special case with a parameter value of $\alpha=2$, but which allows, unlike the Greenberg A Index, to capture finer effects of heterogeneity by endogenously varying the estimation of the degree of data inhomogeneity (Davydov\& Krutikov\& Vorontsova 2019).

In order to determine the direction of human capital development in the macroregion, the study assessed the sensitivity of the human capital index and the dynamics of human capital.

This interdisciplinary research is based on both official statistical information and data from mass surveys and focus groups.

Having conducted the survey in the Yenisey Siberian territories, we used the results to evaluate satisfaction with the quality of life, being one of the leading parameters for the long-term dynamics of human capital. At the same time, we assessed the prospects for migration and demographic changes in the Yenisey Siberian macroregion.

\section{Theoretical framework}

The study is based on the concept of human capital, which determines the view of the population as a limited, specific resource for the economy. The relevance of human resources increases with the transition to $5^{\text {th }}-6^{\text {th }}$ techno-economic paradigm (Mankiw, Romer, Weil, 1992; Aghion, Hovitt, 1998; Lucas, 1988).

Despite the variety of approaches to the definition of human capital (see: Zemtsov,
Smelov, 2018; Angrist, Djankov, Goldberg, Patrinos, 2019; Gemmell, 1996; Ghislandi, Sanderson, Scherbov, 2019; Greenwood, 1997; Kraay, 2018; The Human Capital Project 2018...; OECD) researchers agree that the resource potential of the population from the point of view of social and economic development is determined by such external factors as education, health, and the external environment. Recent research has focused on the role of health and education in the formation of human capital reserves (The Global Human Capital Report 2017..., 2017; The Human Capital Project 2018..., 2018; Valeroa, Reenenb, 2019; Korshunov, Gaponova, Gaponova, 2019; Kelchevskaia, Shirinkina, 2019; Agarkov, Sandler, Sushchenko, 2018; Kliachko, Semionova, 2018). The authors emphasize the role of continuing education, development of project skills and adaptive abilities in the formation of human capital in the digital economy and the importance of creating conditions for the capitalization of human resources in modern Russia. The task is to determine the reserve of human capital and to build long-term forecasts of the territory's development on this basis.

The problem of measuring and evaluating human capital with the purpose of forecasting social and economic development of the macroregion arises from a number of contradictions:

- a component in the structure of the human capital that requires both quantitative and qualitative methods of collecting and processing information;

- the value of human capital depends not only on the rational (external) factors, which are the traditional scope of work for economists, but also on the irrational (internal) factors;

- territorial authorities focus on objective (external) factors of quality of life, which are factors of creation and development of human capital (for example, education, health care, the state of the labour market), while the population concentrates on subjective (internal) factors of quality of life, making decisions on the development of their resource potential and opportunities for its realisation in a particular territory; 
- high heterogeneity of the territories of the resource macroregions of the Russian Federation against the background of the need for a comparative analysis of the human capital indices on the territories of the macroregion.

Approaches to measuring and evaluating human capital were covered in many works (Greenberg, 1956; Doyle, Harmon, Heckman, Tremblay, 2009; Weber, Davydov, 2015, Davydov\& Krutikov\& Vorontsova, 2019; Vorontsova, Khasan at all, 2017). Abundant applied researches on describing and quantifying human capital (Angrist at al., 2019; Dhongde, Haveman, 2015; Index Creative, 2016; Index Far East, 2018; Kraay, 2018) use the principle of linear aggregation of quantitative measurements of various factors at the level of individual "blocks of factors", or at the level of the whole set of factors included in the index, which in turn generates a number of problems and necessitates seeking for their solution (Davydov, Krutikov, Vorontsova, 2019).

The present study uses the OECD definition, which defines human capital as "the knowledge, skills, competencies and attributes embodied in individuals that contribute to the personal, social and economic well-being of people" (Davydov, Krutikov, Vorontsova, 2019; The Well-Being of Nations..., 2001). This is a comprehensive definition which is in line with the research objective, i.e. to assess the applicability of a modification of the human capital index. Taking into account the heterogeneity of the Yenisey Siberian regions, the calculations shall reveal the human capital level (stock) and the impact of social and cultural diversity on innovative development.

\section{Methods}

The approach developed by Center for the Study of Diversity and Social Interactions of New Economic School (NES) (see Report, 2019) was used to choose the method of assessing the level (indicator) of human capital and the selection (inclusion) of individual indicators (in order to describe such a syncretic concept). There have been formulated endogenous indicators used in building the human capital level index for further assessment of the quality of life in individual regions within the country. These indicators are enlisted below:

1. Degree of data aggregation, data volume and structure, quality of the set of socio-economic, demographic, socio-cultural and other indicators which are available for analysis.

2. New horizon of assessment: current level ("stock") of the human capital or its potential for long-term development.

3. Conditions for joint or independent consideration of human capital and other complex (integral in terms of construction) target indicators, such as, for example, living standards or quality of life.

4. Identifiable internal, direct or indirect interconnectedness (correlation) of individual indicators which may be included in the human capital index.

5. Degree of heterogeneity of statistical data at different levels of aggregation.

The present article uses the human capital stock (level) index $H_{\mathrm{t}}^{\mathrm{t}}$ developed by Center for the Study of Diversity and Social Interactions NES on the basis of these works (Weber, Davydov, 2016; Greenberg, 1956; Simpson, 1949).

$$
H_{\mathrm{t}}^{\mathrm{t}}=v_{1, t}^{\alpha_{1}(t)} v_{2, t}^{\alpha_{2}(t)} \ldots v_{n, t}^{\alpha_{n}(t)}
$$

where $v_{i, t}$ - values of separate indicators $i$ $(i=1, \ldots, n)$ at the moment $t$

$$
(t=0,1,2, \ldots) \text {; }
$$

whereas parameters $\alpha_{1}(t)$ of degree of each multiplier represent the so-called "switching function":

$$
\alpha_{i}(t)= \begin{cases}0, & t=0,1, \ldots, \tau_{i}-1, \tau_{i} \\ 1, & t=\tau_{i}+1, \tau_{i}+2, \ldots\end{cases}
$$

Next, based on the use of multi-dimensional statistical and correlation methods at the sub-regional level, including a dual approach of cluster analysis technology, previously tested applied methods for assessing the diversity of Russian regions, also those specified as part of the activities of the Center for the Study of Diversity and Social Interactions (Sotsiokul'turnye faktory..., Sotsiokul'turnye faktory innovatsionnogo..., 2017), we made a list of indicators needed to assess human capital as applied to the analysis of the Yenisey Siberian 
macroregion at the sub-regional, regional and macroregional levels (Table 1).

For the purposes of long-term forecasting and within the context of human capital measurement and evaluation, it is advisable to supplement the statistical evaluation with a subjective assessment of the well-being of the population as a critical factor in the formation and development of the territory's human capital. Behaviour and well-being are linked to each other. The model of complex assessment of well-being should include external and in- ternal contours of factors with balance characteristics (Vorontsova, Khasan, Novopashina, 2015).

External factors include the level of social and economic development of the territory, the state of health care, education, culture and social services provided to the population, characteristics of housing conditions and the labour market.

Internal factors consist of self-evaluation by the group of its ability to demonstrate civic-mindedness, personal experience, subjective

Table 1. Types of indicators for the analysis of human capital stock (based on materials of the first phase of the study)

\begin{tabular}{|c|c|c|}
\hline \multirow{2}{*}{ 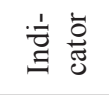 } & \multicolumn{2}{|r|}{ Analysis } \\
\hline & Subregional & Regional \\
\hline 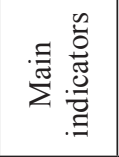 & $\begin{array}{l}-\quad \text { average number of the employed during } \\
\text { the period; } \\
-\quad \text { level of recorded unemployment }\end{array}$ & $\begin{array}{l}-\quad \text { number of people in a region; } \\
-\quad \text { share of the employed people who have higher edu- } \\
\text { cation; } \\
-\quad \text { level of unemployment }\end{array}$ \\
\hline 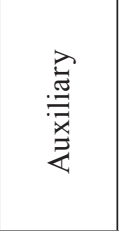 & $\begin{array}{l}\text { - average monthly salary of employees in } \\
\text { the list of certain organisations, as well as the } \\
\text { same indicator for small businesses, micro- } \\
\text { and medium-sized organisations; } \\
-\quad \text { average monthly cash income per capita; } \\
-\quad \text { the consolidated budget own revenues }\end{array}$ & $\begin{array}{l}-\quad \text { gross regional product per capita; } \\
-\quad \text { average cash income per capita }\end{array}$ \\
\hline 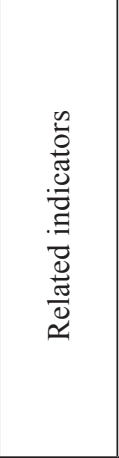 & $\begin{array}{ll}- & \text { fixed assets at full book value; } \\
- & \text { profit of profitable organizations }\end{array}$ & $\begin{array}{l}\text { Indirect factors: } \\
-\quad \text { number of recorded crimes per } 100,000 \text { people; } \\
-\quad \text { sum of the number of theatregoers (per } 1,000 \text { peo- } \\
\text { ple) and the number of museum visits (per } 1,000 \text { peo- } \\
\text { ple); } \\
-\quad \text { total number of patents issued for inventions and } \\
\text { utility models, per } 100,000 \text { people. } \\
\text { For the indicator that defines development potential: } \\
-\quad \text { sum of indicators "number of university students } \\
\text { per } 10,000 \text { inhabitants", "number of faculty per } 100,000 \\
\text { inhabitants" and "number of postgraduate students per } \\
1 \text { million inhabitants" }\end{array}$ \\
\hline 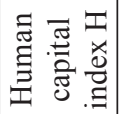 & $\lg (\mathrm{E})+\lg (1-\mathrm{U})+\lg (\mathrm{W})+\lg (\mathrm{Y})^{1}$ & $\lg (\mathrm{N})+\lg (1-\mathrm{U})+\lg (\mathrm{C}) / 3+\lg (\mathrm{P})+\lg (\mathrm{Y})^{2}$ \\
\hline
\end{tabular}

${ }^{1}$ Where $E$ - the average number of the employed people (in thousands), $U$ - registered unemployment rate (in fractions that supplement the value to one), $W$ - the average monthly salary of employees in the list of certain companies (in thousand roubles, adjusted for inflation in dynamics), $Y$ - the average monthly cash income per capita (in thousand roubles, adjusted for inflation in dynamics).

${ }^{2}$ Where $N$ is the population of the region (in $\mathrm{mln}$ people), $S$ is the share of the employed population with higher education, $U$ is the unemployment rate (in fractions that supplement the value to one), $C$ is the sum of the number of theatregoers (per 1,000 people) and the number of museum visits (per 1,000 people), $P$ is the sum of indicators "number of university students per 10,000 people", "number of faculty per 100,000 people" and "number of postgraduate students per 1 million people", $Y$ is average cash income per capita (in thousands of roubles, adjusted for inflation in dynamics). 
attitude towards the ability to implement consumer plans as well as "producer" ones, when members of the group are engaged in a particular area of activity. It is worth noting that in

Table 2. Dynamics of human capital in 2005-2017: logarithmic scale

\begin{tabular}{|c|c|c|c|c|c|c|c|c|c|c|c|c|c|}
\hline \multirow{2}{*}{$\begin{array}{c}\text { Territories } \\
\text { of the Kras- } \\
\text { noyarsk Krai }\end{array}$} & \multicolumn{13}{|c|}{ year } \\
\hline & 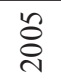 & : & ¿̊̀ & 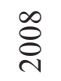 & ठे & 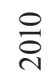 & $\overline{\bar{c}}$ & ָั & $\stackrel{n}{i}$ & 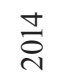 & $\stackrel{n}{\stackrel{n}{2}}$ & $\stackrel{\text { i }}{\stackrel{2}{2}}$ & 혹 \\
\hline Achinsk & 3,4 & $\mathrm{n} / \mathrm{a}$ & $\mathrm{n} / \mathrm{a}$ & 3,5 & 3,5 & 3,5 & 3,6 & 3,6 & 3,6 & 3,6 & 3,6 & 3,5 & 3,5 \\
\hline Bogotol & 2,5 & 2,5 & 2,6 & 2,9 & 2,9 & 2,9 & 2,8 & 2,8 & 2,9 & 2,8 & 2,8 & 2,7 & 2,7 \\
\hline Divnogorsk & 2,7 & 2,8 & $\mathrm{n} / \mathrm{a}$ & 2,9 & 2,9 & 2,8 & 2,8 & 2,9 & 2,9 & 2,8 & 2,8 & 2,8 & 2,8 \\
\hline Kansk & 4,1 & 3,3 & $\mathrm{n} / \mathrm{a}$ & 3,4 & 3,4 & 3,5 & 3,4 & 3,5 & 3,5 & 3,4 & 3,4 & 3,4 & 3,4 \\
\hline Kedrovy & 1,6 & 1,7 & 1,6 & 1,7 & 1,8 & 1,8 & 1,8 & 1,9 & 2,0 & 1,9 & 1,9 & 1,9 & 1,9 \\
\hline Krasnoyarsk & 4,6 & 4,7 & 4,7 & 4,8 & 4,8 & 4,8 & 4,9 & 4,9 & 4,9 & 4,8 & 4,7 & 4,7 & 4,7 \\
\hline Lesosibirsk & 3,1 & 3,1 & 3,2 & 3,6 & 3,6 & 3,6 & 3,5 & 3,4 & 3,4 & 3,4 & 3,3 & 3,3 & 3,3 \\
\hline Minusinsk & 2,8 & 3,0 & 3,2 & 3,3 & 3,3 & 3,3 & 3,4 & 3,4 & 3,4 & 3,4 & 3,3 & 3,2 & 3,3 \\
\hline Norilsk & 4,7 & 4,7 & 4,7 & 4,7 & 4,8 & 4,8 & 4,8 & 4,9 & 4,9 & 4,8 & 4,8 & 4,8 & 4,8 \\
\hline Sosnovoborsk & 2,2 & 2,5 & 2,6 & 2,6 & 2,5 & 2,6 & 2,7 & 2,9 & 2,9 & 2,8 & 2,7 & 2,8 & 2,7 \\
\hline Sharypovo & 2,4 & 2,8 & 2,9 & 2,9 & 3,0 & 3,1 & 3,1 & 3,3 & 3,3 & 3,2 & 3,0 & 3,1 & 3,1 \\
\hline Boguchansky & 2,7 & 2,8 & 2,9 & 3,0 & 3,0 & 3,1 & 3,2 & 3,2 & 3,3 & 3,3 & 3,4 & 3,4 & 3,3 \\
\hline Bolsheuluyskiy & 2,7 & 2,8 & 2,9 & 2,9 & 2,9 & 2,8 & 2,8 & 2,9 & 2,9 & 3,0 & 2,9 & 2,9 & 2,9 \\
\hline Dzerzhinsky & 1,6 & 1,9 & 2,0 & 2,1 & 2,1 & 2,1 & 2,1 & 2,2 & 2,2 & 2,1 & 2,2 & 2,1 & 2,1 \\
\hline Yemelyanovsky & 3,1 & 3,2 & 3,3 & 3,4 & 3,1 & 3,2 & 3,2 & 3,4 & 3,5 & 3,4 & 3,4 & 3,3 & 3,4 \\
\hline Yeniseysky & 2,3 & 2,4 & 2,6 & 2,7 & 2,6 & 2,7 & 2,7 & 2,7 & 2,7 & 3,0 & 2,9 & 2,8 & 2,8 \\
\hline Yermakovsky & 2,0 & 2,2 & 2,2 & 2,4 & 2,4 & 2,4 & 2,4 & 2,5 & 2,5 & 2,5 & 2,5 & 2,5 & 2,5 \\
\hline Idrinsky & 1,8 & 2,0 & 2,1 & 2,2 & 2,2 & 2,2 & 2,2 & 2,3 & 2,3 & 2,3 & 2,3 & 2,2 & 2,3 \\
\hline Ilansky & 2,6 & 2,8 & 2,8 & 2,9 & 2,8 & 2,9 & 2,9 & 2,9 & 3,0 & 2,9 & 2,9 & 2,8 & 2,9 \\
\hline Irbeysky & 1,7 & 1,9 & 2,1 & 2,2 & 2,2 & 2,2 & 2,3 & 2,3 & 2,4 & 2,3 & 2,2 & 2,2 & 2,2 \\
\hline Kazachinsky & 1,9 & 2,0 & 2,1 & 2,0 & 2,0 & 2,0 & 2,0 & 2,2 & 2,3 & 2,2 & 2,1 & 2,1 & 2,2 \\
\hline Kansk & 2,0 & 2,2 & 2,3 & 2,3 & 2,3 & 2,4 & 2,4 & 2,4 & 2,5 & 2,4 & 2,4 & 2,4 & 2,4 \\
\hline Karatuzsky & 1,8 & 2,0 & 2,1 & 2,1 & 2,1 & 2,1 & 2,1 & 2,2 & 2,3 & 2,2 & 2,3 & 2,2 & 2,2 \\
\hline Kezhemsky & 2,7 & 2,9 & 3,1 & 3,2 & 3,2 & 3,2 & 3,3 & 3,3 & 3,3 & 3,2 & 3,0 & 3,0 & 3,0 \\
\hline Motyginsky & 2,4 & 2,4 & 2,8 & 2,9 & 2,8 & 2,9 & 2,9 & 3,0 & 3,1 & 3,0 & 3,0 & 3,0 & 3,0 \\
\hline Sukhobuzimsky & 2,2 & 2,3 & 2,4 & 2,5 & 2,5 & 2,5 & 2,5 & 2,5 & 2,6 & 2,5 & 2,4 & 2,4 & 2,4 \\
\hline $\begin{array}{c}\text { Taimyr } \\
\text { (Dolgano-Nenets) }\end{array}$ & 3,6 & 3,7 & 3,7 & 3,7 & 3,8 & 3,8 & 3,8 & 3,8 & 3,8 & 3,8 & 3,8 & 3,8 & 3,8 \\
\hline Taseevsky & 1,7 & 2,0 & 2,1 & 2,2 & 2,2 & 2,2 & 2,1 & $\mathrm{n} / \mathrm{d}$ & 2,2 & 2,1 & 2,1 & 2,1 & 2,1 \\
\hline Turukhansk & 2,5 & 2,9 & 3,0 & 3,4 & 3,5 & 3,7 & 3,7 & 3,9 & 3,8 & 3,8 & 3,7 & 3,7 & 3,7 \\
\hline Tyukhtet & 1,6 & 1,8 & 2,0 & 2,0 & 2,0 & 2,0 & 2,0 & 2,0 & 2,1 & 2,0 & 2,0 & 1,9 & 2,0 \\
\hline Sharypovsky & 2,6 & 2,6 & 2,6 & 2,6 & 2,5 & 2,6 & 2,6 & 2,8 & 2,9 & 3,1 & 2,9 & 2,8 & 2,8 \\
\hline Shushensky & 3,5 & 2,5 & 2,6 & 2,8 & 2,8 & 2,8 & 2,8 & 2,8 & 2,9 & 2,8 & 2,7 & 2,6 & 2,6 \\
\hline Evenkiysky & 3,1 & 3,2 & 3,3 & 3,3 & 3,4 & 3,4 & 3,3 & 3,3 & 3,4 & 3,4 & 3,5 & 3,5 & \\
\hline
\end{tabular}

Note: "n/a": not enough data to make calculations.

Source: data of the state statistics. 
the past citizenship was seen as political participation. Now citizenship is seen as participation in social activities and openness of social opportunities. It literally means taking part in all kinds of social decisions.

Thus, the main indicators of correct and comprehensive characterization of human capital at the level of individual regions and the macroregion as a whole are the following:

- Well-being (through social participation, creativity, position, love, illness, etc.) or lack of wellness;

- Safety;

- Compliance with expectations (claims);

- Internal resources to overcome uncertainty of threats.

It is advisable to use the following variables as independent: age, modality, aspirations, and economic / demographic / social / activity factors. Here we needed to separate the factors that determine behaviour and the combination of factors. In other words, we believe that objectified (external) factors and perceptions of them do not determine behaviour directly. Behaviour changes under the influence of internal factors, which in turn form personal resource opportunities for decision-making and the implementation of decisions.

Accordingly, every field of the well-being should be evaluated in the following areas:

availability ("How much is it available for me?"); me?");

importance ("How important it is for

satisfaction ("How much am I satisfied with it?");

relevance ("How much is it relevant for me at the moment?")

opportunity to influence ("How can I interfere in the situation, initiate the changes?");

individual's own prospects ("What are my prospects in this direction?").

\section{Results and discussion}

To calculate indices at the macroregional level, we used aggregated (weighted average) values of indices obtained from regional data.

Thus, the human capital index developed within the project provides an opportunity to analyse the human capital dynamics at the sub-regional, regional and macro-regional levels, to highlight positive and negative trends, and to plan additional social research to clarify the factors of influence.

For example, Table 3 shows a decrease in the human capital index in all subjects of the Yenisey Siberian macroregion. In the Krasnoyarsk Krai and the Republic of Khakassia the human capital index has been falling since 2017 at an accelerated pace (Fig. 1), mainly due to a decrease in the integral indicator "number of university students per 10,000 people; number of faculty per 100,000 people; number of postgraduate students per 1 million people", meanwhile in the Republic of Khakassia the integral indicator "number of theatregoers and number of museum visits per 1,000 people" is also falling. The human capital level in the Republic of Tuva is generally low, the number of students and teachers in higher education has significantly decreased, but there is a positive trend in a series of other indicators, in contrast to the Republic of Khakassia and the Krasnoyarsk Krai.

Direct comparison of subjects due to their high heterogeneity is not sufficiently correct, so it is recommended to carry out calculations for 8 meso-regional clusters (Bukharova et al., 2019): 6 clusters (Eastern, Western, Angarsky, Northern, Central, Southern) on the territory of the Krasnoyarsk Krai and 2 clusters in the territory of the Republics of Khakassia and Tyva.

806 people from Yenisey Siberia took part in the survey for the purpose of testing the methodology, the sample was typical. $67.7 \%$ of respondents were women, the age of respondents ranged from 13 to 64 years old (women under 63 years old), the average age was 25.4 years (for women -26.6 years, for men -22.7 years) and the median age was 22 years (for women -23 years, for men -20 years). The overwhelming majority of respondents live in cities. There were 4 people living in villages and 30 respondents living in urban-type settlements. The majority of respondents have a higher education $(40.2 \%)$ or incomplete higher education $(21.85 \%)$. In general, the samples show on average lesser satisfaction with the level of cultural facilities, necessary education- 
Table 3. Dynamics of human capital index at regional level

\begin{tabular}{|c|c|c|c|c|c|c|c|c|c|c|c|c|}
\hline \multirow{2}{*}{$\begin{array}{l}\text { Indicators and re- } \\
\text { sulting indices }\end{array}$} & \multicolumn{4}{|c|}{ Krasnoyarsk Krai } & \multicolumn{4}{|c|}{ Republic of Khakassia } & \multicolumn{4}{|c|}{ Republic of Tyva } \\
\hline & 2015 & 2016 & 2017 & 2018 & 2015 & 2016 & 2017 & 2018 & 2015 & 2016 & 2017 & 2018 \\
\hline $\begin{array}{l}\text { Population (thousands of } \\
\text { people) }\end{array}$ & 2866 & 2875 & 2876 & 2874 & 537 & 537 & 538 & 536 & 316 & 318 & 322 & 324 \\
\hline Unemployment rate (\%) & 6.2 & 6.1 & 5.7 & 4.9 & 5.8 & 6.3 & 4.9 & 5.2 & 18.6 & 16.6 & 18.3 & 14.8 \\
\hline $\begin{array}{l}\text { Sum of the number of } \\
\text { theatregoers (per } 1,000 \\
\text { people) and the number of } \\
\text { museum visits (per } 1,000 \\
\text { people) }\end{array}$ & 940 & 931 & 940 & 929 & 900 & 879 & 903 & 747 & 258 & 236 & 293 & 286 \\
\hline $\begin{array}{l}\text { Sum of indicators "num- } \\
\text { ber of university students } \\
\text { per } 10,000 \text { people", "num- } \\
\text { ber of faculty per } 100,000 \\
\text { people" and "number of } \\
\text { postgraduate students per } \\
1 \text { million people" }\end{array}$ & 1179 & 1095 & 1021 & 810 & 420 & 392 & 366 & 307 & 499 & 438 & 354 & 287 \\
\hline $\begin{array}{l}\text { Average cash income per } \\
\text { capita (in thousands of rou- } \\
\text { bles) }\end{array}$ & 27.1 & 21.3 & 28 & 30 & 20.8 & 21.5 & 21.2 & 21.6 & 15.3 & 21 & 14 & 15.6 \\
\hline Index & 4.39 & 4.36 & 4.33 & 4.24 & 3.21 & 3.18 & 3.16 & 3.05 & 2.83 & 2.78 & 2.71 & 2.64 \\
\hline
\end{tabular}

Source: data of the state statistics.

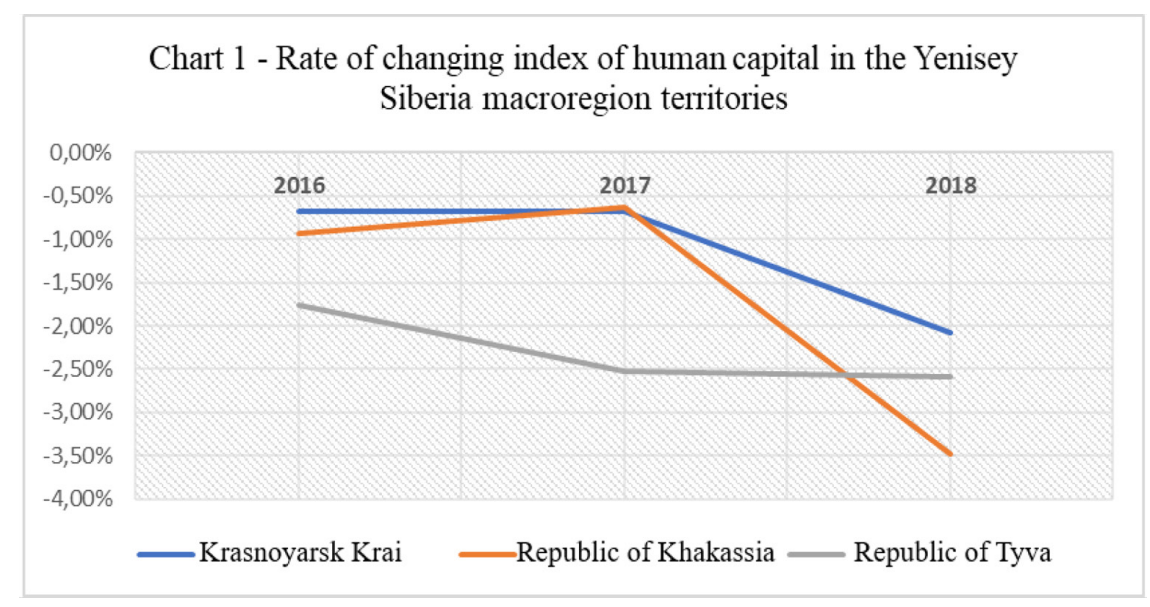

Fig. 1

al services and the comfort of the urban environment compared to the declared importance (Table 4).

The difference in assessments between the desired and actual states was 1.44 for ecological safety, 1.36 for safety from crime, and 1.35 for health, which is catastrophically high for a five-point scale (the minimum gap is 0.29 points, which corresponded to assessing the desired and actual state in relations with parents).

\section{Conclusion}

Within the scope of the problem set in the study of measuring and assessing human capital with the purpose to predict the social and economic development of the territory of the 
Table 4. Social well-being of the Yenisey Siberia residents

\begin{tabular}{|c|l|c|c|c|}
\hline No. & \multicolumn{1}{|c|}{ Indicator } & Availability & Importance & Satisfaction \\
\hline 1. & Cultural objects (theatres, museums, exhibitions, cinemas) & 3.905 & 3.996 & 3.63 \\
\hline 2. & $\begin{array}{l}\text { Places of purchase of necessary goods (supermarkets, shop- } \\
\text { ping centers) }\end{array}$ & 4.003 & 4.217 & 3.694 \\
\hline 3. & $\begin{array}{l}\text { Spiritual life of society (religion, spiritual communities and } \\
\text { others) }\end{array}$ & 3.6 & $2.976^{*}$ & $3.384^{*}$ \\
\hline 4. & $\begin{array}{l}\text { Specialized institutions for the rehabilitation/maintenance/ } \\
\text { promotion of population's health and physical development } \\
\text { (hospitals, fitness centers, sanatoriums and other) }\end{array}$ & 3.148 & 4.091 & $2.948^{*}$ \\
\hline 5. & Educational services required by the individual & 3.399 & 4.179 & 3.278 \\
\hline 6. & Walkways, crossings (ease of travel in the city) & 3.349 & 4.278 & 3.176 \\
\hline 7. & Public transport (ease of travel in the city) & 3.334 & 4.26 & 3.132 \\
\hline 8. & Personal transportation (ease of travel in the city) & $3.299^{*}$ & $3.915^{*}$ & $3.193^{*}$ \\
\hline 9. & Parking spaces (ease of travel in the city) & $2.755^{*}$ & $3.871^{*}$ & $2.848^{*}$ \\
\hline
\end{tabular}

Note: the average values of responses on a five-point scale are given, where 1 stands for "very bad", 5 is "very good".

* More than $15 \%$ did not answer the question.

Source: survey data.

macroregion, the following conclusions can be drawn from the results of the study.

The study of the available data for the indicators' selection was carried out at the first stage of the study in 2019 (Bukharova et al., 2019; Davydov, Krutikov, Vorontsova, 2019). It used multidimensional statistical methods and correlation analysis, verification and testing of the models developed at the first stage of the project with new statistical data. The data collected have proven their stability (robustness) within the existing structure, which allows researchers to use the proposed indices in the future.

At present, the structure and quality of the available statistical information required to calculate the human capital index at the regional and subregional levels limit the possibilities for more detailed testing of the developed indices, as well as making possible adjustments. Along with this, the indicators selected for the creation of the human capital index are focused on a relative quantitative assessment of the stock and basically do not assess the quality of human capital (completely ignoring the indicators of social well-being of the population).

In this regard, in order to correctly assess the current situation in the human cap- ital sphere of the macroregion (primarily in the field of knowledge, abilities, skills, health status, pedagogical methods and educational programs), we consider it important to organize:

1) longitudinal (panel) study of households, being representative according to the identified clusters (8 clusters in the Yenisey Siberia);

2) representative annual survey of the population of the macroregion of the Yenisey Siberia for various aspects of well-being. The researchers shall assess not only social well-being, but also civic and existential well-being in relation to employment and the quality of working life.

The results of the study made it possible to design steps for modelling in the future the relationship between objective and subjective assessments of human capital.

To prepare and pursue a policy (of regional authorities or other development institution) to increase the level of human capital in such diverse regions as the Krasnoyarsk Krai, the Republic of Tyva and the Republic of Khakassia, it is necessary to diversify goals and methods for each region (following the common goal for the macroregion Yenisey Siberia 
as a whole), develop target indicators in certain areas and identify stakeholders who will be the drivers of strategy implementation at different stages.

\section{References}

Agarkov, G.A., Sandler, D.G., Sushchenko, A.D. (2018). Finansovaya i sotsial'naya uspeshnost' vypusknikov universitetov v Ural'skom regione. Problemy i puti resheniya [Financial and social success of university graduates in the Ural region. Problems and solutions]. In Ekonomika regiona [Economy of the region], 14, (4), 1312-1326.

Akchurina, D.D., Weber, Sh., Davydov, D.V., Krutikov, D.V., Khazanov, A.A. (2015). Izmerenie raznoobraziia: teoriia i sotsial'no-ekonomicheskie prilozheniia [Measurement of diversity: theory and socio-economic applications]. In Sovremennaia ekonomika: problem i resheniia [Modern economy: problems and solutions], 2, 8-28.

Aghion, P., Howitt, P.W. (1998). Endogenous Growth Theory. Cambridge, MA: MIT Press.

Angrist, N., Djankov, S., Goldberg, P.K., Patrinos, H.A. (2019). Measuring Human Capital. Policy Research Working Paper 8742. Education Global Practice \& Development Economics.

Bukharova, E.B., Vorontsova, I.P., Semenova, A.R., Vitkovskaya, L.K., Popelnitskaya, I.M., Drobyshev, I.A. (2019). Methodological approaches to homogenous regional clusters formation for human capital and quality of life assessment in the Yenisei Siberia macro-region. In Journal of Siberian Federal University. Humanities \& Social Sciences, 12, 12, 2137-2154.

Creativ Capital Index (2016). Sotsial'nyy proyekt PricewaterhouseCoopers International Limited [Social project Pricewaterhouse Coopers International Limited]. Available at: http://creativecapitalindex. com/benchmarking

Dhongde, Shatakshee \& Haveman, Robert (2017). Multi-Dimensional Deprivation in the U.S. In Social Indicators Research: An International and Interdisciplinary Journal for Quality-of-Life Measurement, Springer, 133(2), 477-500, September.

Gemmell, N. (1996). Evaluating the impacts of human capital stocks and accumulation on economic growth: some new evidence. In Oxford Bulletin of Economics and Statistics, 58 (1), 9-28.

Gini, C. (1912). Variabilità e Mutuabilità. Contributo allo Studio delle Distribuzioni e delle Relazioni Statistiche. C. Cuppini, Bologna. $109-115$

Greenberg, J. (1956). The Measurement of Linguistic Diversity. In Language, 32 (1),

Ghislandi, S., Sanderson, W.C., Scherbov, S. (2019). A simple measure of human development: the human life indicator. In Population and development review, 45 (1), 219-233.

Greenwood, D.T. (1997). New Developments in the Intergenerational Impacts of Education. In International Journal of Education Research, 27 (6), 503-512.

Davydov, D.V., Krutikov, D.V., Vorontsova, I.P. (2019). Approaches to the Study of Human Capital within a Set of Socio-Economic and Socio-Cultural Factors on the Example of Yenisei Siberia. In Journal of Siberian Federal University. Humanities \& Social Sciences, 12, 4, 583-599.

Davydov, D., Weber, S. (2016). A simple characterization of the family of diversity indices. In Economics Letters, 147, 121-123.

Doyle, O., Harmon, C.P., Heckman, J.J., Tremblay, R.E. (2009). Investing in early human development: Timing and economic efficiency. In Economics and Human Biology, 7, 1-6.

Indeks razvitiia chelovecheskogo kapitala na Dal'nem Vostoke [Far East Human Capital Development Index]. In Agentstvo po razvitiiu chelovecheskogo kapitala na Dal'nem Vostoke [Far East Human Capital Development Agency]. Moscow, 2018.

Itogi Vserossiiskoi perepisi naseleniia 2010 goda. Tom 4: Natsional'nyi sostav i vladenie iazykami [Results of the All-Russian Population Census 2010. Volume 4: National composition and language proficiency, citizenship]. Available at: http://www.gks.ru/free_doc/new_site/perepis2010/croc/perepis_itogil612.htm 
Kelchevskaia, N.R., Shirinkina, E.V. (2019). Regional'nye determinant effektivnogo ispol'zovaniia chelovecheskogo kapitala $\mathrm{v}$ tsifrovoi ekonomike [Regional determinants of efficient use of human capital in digital economy]. In Ekonomika regiona [Regional economy], 15, 2, 465-482

Khakasskii respublikanskii statisticheskii ezhegodnik: Stat. sbornik [Khakass Republican Statistical Yearbook: statistics collection]. Abakan: Krasnoyarskstat, 2019, 433 p.

Kliachko, T.A., Semionova, E.A. (2018). Vklad obrzovaniia v sotsial'no-ekonomicheskoe razvitie regionov Rossii [The contribution of education to the social and economic development of Russian regions]. In Ekonomika regiona [Regional economy], 14, 3, 791-805

Korshunov I.A., Gaponova O.S., Gaponova N.S. (2019). Obucheniye i obrazovaniye vzroslykh v kontekste ekonomicheskogo razvitiya regionov [Teaching and education of adults in the context of economic development of regions]. In Ekonomika regiona [Economy of the region], 15 (1), 107-120.

Kraay, A. (2018). Methodology for a World Bank Human Capital Index. Background Paper to the 2019 World Development Report. In Policy Research Working Paper 8593. Development Research Group, Development Economics.

Mankiw, N.G., Romer, D., Weil, D.N. (1992). A Contribution to the Empirics of Economic Growth. In Quarterly Journal of Economics, 107, May, 407-37.

Krasnoyarskii kraevoi statisticheskii ezhegodnik: Stat. sbornik [Krasnoyarsk regional statistical yearbook: statistics collection]. Krasnoyarsk: Krasnoyarskstat, 2019, 500 p.

Lucas, R.E.Jr. (1988). On the Mechanics of Economic Development. In Journal of Monetary Economics, 22 (1), 3-42.

Otchiot o provodimom nauchnom issledovanii po napravleniiu "Izuchenie raznoobraziia $i$ sotsial'nykh vzaimodeistvii s fokusom na ekonomike i obshchestve Rossii". Etap 2 (promezhutochnyi) [Report on the ongoing research in the field of "Study of diversity and social interaction with a focus on the economy and society of Russia". Stage 2 (intermediate)]. Moscow: Center for the Study of Diversity and Social Interactions NES, 2014.

Regiony Rossii 2019. Sotsial'no-ekonomicheskie pokazateli: sbornik statei [Regions of Russia 2019. Social and economic indicators: collection of articles]. Moscow: Rosstat. Available at: https://rosstat.gov. $\mathrm{ru} / \mathrm{bgd} / \mathrm{regl} / \mathrm{b} 19 \_14 \mathrm{p} /$ Main.htm

Simpson, E. (1949). Measurement of diversity. In Nature, 163, 688.

Sotsiokul'turnye faktory innovatsionnogo razvitiia i uspeshnoi implementatsii reform. Nauchnyi doklad [Sociocultural factors for innovative development and successful implementation of reforms. Scientific report]. Moscow: Center for Strategic Development, 2017.

Statisticheskii ezhegodnik Respubliki Tyva: Stat. sbornik [Statistical Yearbook of the Republic of Tyva: statistics collection]. Kyzyl: Krasnoyarskstat, 2019, 425 p.

The Global Human Capital Report 2017. World Economic Forum, 2017.

The Human Capital Project 2018. International Bank for Reconstruction and Development. The World Bank Group. Washington, 2018.

The Well-Being of Nations: The Role of Human and Social Capital. OECD. Paris: OECD Publishing, 2001.

Valeroa, A., Reenenb, J.V. (2019). The economic impact of universities: Evidence from across the globe. In Economics of Education Review, 68, February 2019, 53-67. https://doi.org/10.1016/j.econedurev.2018.09.001

Vorontsova, I.P., Novopashina, L.A., Khasan, B.I. (eds.) (2015). Professional'no-strukturnye i psikhologicheskie aspekty modeli upravleniia i monitoringa kachestva zhizni v regione [Professional-structural and psychological aspects of the model of management and monitoring of quality of life in the region]. Siberian Federal University, Institute of Economics, Management and Environmental Studies. Krasnoyarsk.

Vorontsova, I., Khasan, B., Novopashina, L., Vitkovskaya, L., Krasnousov, S. (2017). The methodological approach to the monitoring of migration flows for the development of a differentiated territorial policy. In the collection: 4th international multidisciplinary scientific conference on social sciences and arts sgem 2017. C. 263-270. 
Weber, Sh., Davydov, D.V. (2015). Ekonomika raznoobraziia: podkhody, metody, rezul'taty [Economics of diversity: approaches, methods, results]. In Ekonomika i matematicheskie metody [Economics and mathematical methods], 51, 4, 3-13.

Zemtsov, S.P. Smelov Y.A. (2018). Faktory regional'nogo razvitiia v Rossii: geografiia, chelovecheskii kapital i politika regionov [Factors of regional development in Russia: geography, human capital and regional politics]. In Zhurnal Novoi ekonomicheskoi assotsiatsii [Journal of new economic association], 4 (40), 84-108.

\title{
Оценка человеческого капитала макрорегиона на примере Енисейской Сибири
}

\author{
И.П. Воронцова, А.Р. Семенова, \\ Л.К. Витковская, И.А. Дробышев \\ Сибирский федеральный университет \\ Российская Федерация, Красноярск
}

\begin{abstract}
Аннотация. Статья посвящена проблеме измерения и оценки человеческого капитала ресурсного макрорегиона, территория которого отличается высоким уровнем социально-экономической асимметрии. Представлены результаты апробации модифицированного индекса человеческого капитала в контексте междисциплинарного подхода. Наряду со статистическими данными исследование опиралось на опросные данные. Удовлетворенность населения качеством жизни является ключевым индикатором динамики человеческого капитала в долгосрочном периоде. Представлены рекомендации по развитию информационного обеспечения территориальной политики.
\end{abstract}

Ключевые слова: оценка человеческого капитала, макрорегион Енисейская Сибирь, социально-экономические индексы, качество жизни.

Исследование было проведено в рамках грантовой поддержки РФФИ, Правительства Красноярского края, Красноярского краевого фонда поддержки научной и научно-технической деятельности по проекту «Формальные подходы и практика измерения человеческого капитала в контексте оценки качества жизни населения территории (на материале макрорегиона Енисейская Сибирь)» № 18-410-242006 (r_mk).

Научная специальность: 08.00.00 - экономические науки. 